\title{
OA08.02. Differential acute effects of real and sham acupuncture on mu-opioid receptor availability in treatment naive and conditioned chronic pain patients
}

\author{
N Akbar , , Zubieta, T Love, D Clauw, R Harris \\ From International Research Congress on Integrative Medicine and Health 2012 \\ Portland, Oregon, USA. 15-18 May 2012
}

\section{Purpose}

Previous studies suggest acupuncture analgesic effects involve the release of endogenous opioid peptides. We have previously shown that while both acupuncture and sham reduced clinical pain in fibromyalgia (FM), only acupuncture increased mu-opioid receptor (MOR) baseline receptor availability in vivo (binding potential, BP). Here we investigated whether real and sham acupuncture were associated with differential changes in MOR $\mathrm{BP}$ in FM patients that were naive to acupuncture as compared to conditioned patients.

\section{Methods}

20 female FM patients (mean (SD) age 44.3 (13.6) years) were randomized to acupuncture $(n=10)$ or sham $(n=10)$ treatments over four weeks. Acupuncture involved insertion of nine needles into the body whereas sham did not penetrate the skin. Positron emission tomography (PET) with the mu-opioid radiotracer [11C] carfentanil was performed during the first and ninth treatments. Each session included a 'baseline' scan prior to needle insertion and 'treatment' scan during needle insertion. We compared the difference in MOR BP between baseline and treatment, before and after 4 weeks of acupuncture versus sham. MOR quantification performed with Logan plots resulting in voxel-by-voxel maps of MOR BP. Images were analyzed with SPM 5.

\section{Results}

Real and sham acupuncture differed in their acute effects on MOR BP. The effect was localized in the left

University of Michigan, Ann Arbor, USA temporal pole and left amygdala/striatum (significant after correction for multiple comparisons, $\mathrm{p}<.05)$. The treatment effect was largely due to a change in $\mathrm{BP}$ with sham after 4 weeks.

\section{Conclusion}

Acupuncture and sham resulted in differential acute effects on MOR binding in treatment naive as compared to conditioned patients. These findings could demonstrate a conditioned placebo response in sham treated chronic pain patients.

Published: 12 June 2012

doi:10.1186/1472-6882-12-S1-030

Cite this article as: Akbar et al.: OA08.02. Differential acute effects of real and sham acupuncture on mu-opioid receptor availability in treatment naive and conditioned chronic pain patients. BMC

Complementary and Alternative Medicine 2012 12(Suppl 1):O30.

Submit your next manuscript to BioMed Central and take full advantage of:

- Convenient online submission

- Thorough peer review

- No space constraints or color figure charges

- Immediate publication on acceptance

- Inclusion in PubMed, CAS, Scopus and Google Scholar

- Research which is freely available for redistribution

\section{C)

@ 2012 Akbar et al; licensee BioMed Central Ltd. This is an Open Access article distributed under the terms of the Creative Commons Attribution License (http://creativecommons.org/licenses/by/2.0), which permits unrestricted use, distribution, and reproduction in any medium, provided the original work is properly cited. 